Article

\title{
Research on Cross-Domain Study Curricula in Cyber-Physical Systems: A Case Study of Belarusian and Ukrainian Universities
}

\author{
Anatolijs Zabasta ${ }^{1, * \mathbb{C}}$, Joan Peuteman ${ }^{2}$, Nadezda Kunicina ${ }^{1}$, Volodymyr Kazymyr ${ }^{3}$, \\ Sergey Hvesenya ${ }^{4}$, Andrii Hnatov ${ }^{5}$, Tatsiana Paliyeva ${ }^{6}\left(\mathbb{D}\right.$ and Leonids Ribickis ${ }^{1}$
}

1 Institute of Industrial Electronics and Electrical Engineering, Faculty of Electrical and Environmental Engineering, Riga Technical University, Azenes 12/1, LV1048 Riga, Latvia; Nadezda.Kunicina@rtu.lv (N.K.); Leonids.Ribickis@rtu.lv (L.R.)

2 Faculty of Engineering Technology, Department of Electrical Engineering, KU Leuven, Bruges Campus Spoorwegstraat 12, 8200 Bruges, Belgium; joan.peuteman@kuleuven.be

3 Information and Computer Systems Department, Chernihiv National Technological University, Shevchenko, 95, 14035 Chernihiv, Ukraine; vvkazymyr@stu.cn.ua

4 Mechanics and Mathematics Faculty, Belarusian State University, Nezavisimosti av. 4, 220030 Minsk, Belarus; s.hvesenya@gmail.com

5 Vehicle Electronics Department, Kharkiv National Automobile and Highway University, Yaroslava Mudrogo st, 25, 61002 Kharkiv, Ukraine; kalifus76@gmail.com

6 Pedagogic and Psychology Department, Mozyr State Pedagogical University, 28 Studencheskaya Str., Office 228, 247760 Mozyr, Belarus; 0605tanya1980@rambler.ru

* Correspondence: Anatolijs.zabasta@rtu.lv; Tel.: +371-29-232-872

Received: 28 August 2020; Accepted: 30 September 2020; Published: 15 October 2020

\begin{abstract}
The increasing importance of continuingly complex Cyber-Physical Systems (CPS) challenges and encourages universities worldwide to organize up-to-date CPS oriented educational programs. The Erasmus+ project "CybPhys" aims to support CPS oriented educational programs in Belarus and Ukraine. We put forward a hypothesis that the educational situation, training opportunities, situation of the labor market, and general economic development are related to each other and can vary depending on the region. In order to validate our hypothesis and to provide input to curricula modernizations, an in-depth study in the form of surveys was conducted in the years 2019-2020. The results of the study showed that the differences between the perceptions of stakeholders in different regions of one country were more significant than the deviations between the global evaluation marks obtained from Belarusian and Ukrainian respondents. In order to increase the synergy of the CybPhys partners, the transdisciplinary and T-shape skills approaches are introduced to the education programs of the partner's universities. An innovative ICT based teaching and learning environment and associated teaching methodologies will be developed. The research provides valuable input to the development of industry and research-oriented cross-domain study programs in Cyber-Physical Systems focused on the needs of Belarusian and Ukrainian industries.
\end{abstract}

Keywords: Cyber-Physical Systems; T-shape approach; Student's t-distribution; survey; engineering curriculum

\section{Introduction}

\subsection{Cyber-Physical Systems}

Cyber-Physical Systems are complex systems; they consist of distributed and networked computing elements. Algorithmic and software engineering knowledge has been integrated. Often interactions 
with human users take place, implying a man-machine interface is needed. Sensor and actuator technologies are commonly combined.

Cyber-Physical Systems (CPS) are used in a very broad range of applications. When considering emerging technologies like smart cities, smart houses, smart grids, logistic networks, intelligent traffic infrastructure, healthcare, etc., CPS are indispensable. In technologically developed regions of Belarus and Ukraine, different complex infrastructures need a large number of CPS and associated systems. An efficient operation of the entire economy relies on these CPS, which are used in a broad range of industrial branches, manufacturing infrastructure, transport, energy-related systems, etc. [1].

When considering CPS, physical objects and computational resources are integrated and there is a continuous coordination between them. Typical for CPS are real-time capabilities, real-time reactivity and real-time control engineering [2]. Due to the presence of the world-wide web, with wired or wireless communication facilities, not only information but also additional software services are available. Due to the connection with the world-wide web, which is an open system, the CPS can be more vulnerable to malicious cyber-attacks from outside implying cyber security is an important aspect. CPS are tightly connected with the notion "Smart systems", which have become a driving force behind almost all product innovations, and smart-enabled solutions can be found in almost every application field: transportation, health, manufacturing, the Internet of things (IoT), energy, natural resources and security [3,4]. Although CPS, as complete systems, are built to fulfil certain applications, many technological topics and issues in these systems are common to other research areas (application independent) and as such, CPS can be regarded as enabling technologies [5]. Architecture, engineering and design approaches have to be radically rethought under the requirements and constraints of the CPS-based Industrial Systems, taking in account such key issues as real-time interaction, complexity, safety, cross-layer collaboration, heterogeneity, scalability etc. [6]. The authors of [7] pointed out limitations for development of future CPS due to varying environments, uncertainty and composability of CPS. The issue of collaboration between humans and intelligent systems and establishing of trustworthiness also causes limitations in dealing with future CPS. The paper [8] discuss the practical issues of design of CPS. A data twin oriented (DT) simulation Model for an IoT-aided bench-scale factory system was constructed IoT-aided manufacturing system. Security requirements identification for heterogeneous CPS components is considered as a critical aspect in [9]. A security framework for a smart car parking system has been investigated taking into account as the software as the hardware perspective.

The development of CPS is multidisciplinary [10] on its own i.e., combining a large number of scientific and technical disciplines is mandatory: physics, mechanics, electronics, mechatronics, (digital) control engineering, computer technology, ICT, data communication, etc. CPS systems are developed by engineers educated in multiple domains [11]. For an individual engineer, it is not sufficient to master its own engineering specialization. The engineer must be able to understand the entire heterogeneous system (at least at some basis level) which will allow him to collaborate with engineers and technicians specialized in other relevant domains. Engineers having these attitudes allow to form cross disciplinary teams [12].

The interdisciplinarity might be considered as a synthesis of different knowledge in order to obtain a new solution to a complex problem, therefore the modern trend towards interdisciplinarity becomes a necessity due to the range of complex tasks, and requirements of differentiation and integration of knowledge $[13,14]$. Interdisciplinary continuing professional education provides opportunities for professionals to learn alongside one another, conversing and negotiating new knowledge about emerging practices [15]. The Industry 4.0 (I4.0) that emphasizes smart industries requirements to cooperate with multiple processes and professions, has gradually changed employee education and skills requirements. Furthermore, I4.0 paradigm proposes for a better understanding of interdependence between human resources maturity and the level of external partnerships [16,17]. Lazar et al. [18] defined advance education (AA) as an organized process of generating knowledge and competencies, which aiming to solve future problems that are consistent with global trends and national development 
programs. He also formulated basic principles for the introduction of AA, such as context analysis, monitoring scientific and technological achievements, ability to forecast competencies, etc. [18].

As explained by [11], so-called T-shaped engineers are needed. These T-shaped people have in-depth knowledge and understanding of their own specialization (the vertical part of the T) but they also have a broad perspective when they need to communicate and collaborate as a member of a multidisciplinary team (the horizontal part of the T). This collaboration implies that both sufficiently broad technical skills and human interpersonal skills are needed. The traditional restrictions many technically skilled graduates face are as follows:

- the graduates have difficulties dealing with heterogeneous and multidisciplinary problems,

- the graduates have difficulties dealing with safety-critical aspects, security, and resilience,

- the graduates have difficulties cooperating in multi-disciplinary teams.

When developing curricula to prepare future CPS specialists, technical specialization, a broad technical perspective, and decent interpersonal skills need to be developed.

\subsection{The Erasmus+ Project CybPhys}

The Erasmus+ project "Development of practically-oriented student-centered education in the field of Cyber-Physical Systems" (CybPhys) [19] focuses on curricula modernization taking into account the results provided by an analysis of the labor market needs. Not only the present needs of the labor market are important, but it is also important to forecast the developments in this labor market in the nearby future. Recommendations of industrial partners, non-governmental organizations, design centers, research institutions, and Higher Education Institutions in Belarus and Ukraine need to be taken into account.

The CybPhys started its activities in November 2019 for a duration of three years. CybPhys faces the needs of the Eastern Partnership Countries, Belarus and Ukraine. Three Belarusian universities participate in the project: Belarusian State University (BSU), Gomel State University (GSU), and Mozyr State Pedagogical University (MSPU). Three Ukrainian universities participate in the project: Chernihiv National Technological University (CNTU), Kharkiv National Automobile and Highway University (KhNAHU), and Kryvyi Rih National University (KNU). Additionally, also five associated partners from Belarus and Ukraine participate. Finally, three EU universities participate in the project. Three European universities share their knowledge and experience among the project partners: University of Leuven (KU Leuven) from Belgium, University of Cyprus (UCY), and Riga Technical University (RTU) from Latvia, which is a leading partner of the consortium.

Starting the project, we were aware the situation differs from university to university and from region to region. Each university has its own history, which is closely determined by the history of its region. The present situation of the labor market also strongly depends on the region, therefore, the situation in Belarus and Ukraine is not entirely the same. Preliminary research arranged at the beginning of the project by the six partner universities BSU, GSU, MSPU, CNTU, KhNAHU, and KNU, revealed rather different ex-ante educational situations [20]. Furthermore, partner universities also face different labor market requirements [21], as it was revealed by a preliminary survey of industry representatives and other stakeholders arranged at the preparation stage of the CybPhys proposal.

Therefore, we put forward a hypothesis that the educational situation, the training opportunities, the situation of the labor market, and the general economic development are related to each other and vary depending on the specific region [22]. All these factors come together due to a certain homogeneity in a regional area:

- there are (possibly) political borders;

- there is internal cohesion implying the needs are similar;

- a decent educational system in a region, capable of attracting high technology companies, research institutions, educational institutions, and training opportunities (e.g., provided by universities and colleges), is needed; 
- coordinated collaboration between academia, industry, and governments is important since it stimulates the general development of the region.

Preliminary surveys of research institutions, professional associations, companies, and Higher Educational Institutions in Belarus and Ukraine have been performed [21,23,24] in years 2016-2018 aiming to determine the needs and perceptions of potential employers. The answers revealed a high interest of the employers to the knowledge and skills of graduates required to develop and apply CPS. The answers also revealed the importance of specific requirements when organizing internships and the importance of an appropriate proportion between the theoretical and practical parts of the education process [23]. There were differences between the answers formulated in Belarus and Ukraine. The Belarusian respondents, who represented mainly research institutions, were mainly interested in modeling the CPS. The Ukrainian respondents, who represented mainly transport, logistic, and mining industry companies, mainly revealed interest in applications for control processes in transportation, energy production, and manufacturing. These survey results inspired the targets, deliverables, and methodology of the CybPhys project $[19,25,26]$.

In order to validate our hypothesis and to provide input to the process of the curricula modernizations, an in-depth study in a form of surveys was conducted from the end of 2019 to the beginning of 2020. We proceeded from the fact that well-thought-out curriculum development is possible thanks to a comparison and an analysis of the present educational situations at the six participating universities in Belarus and Ukraine [20] with the results obtained by the surveys of industry representatives and other stakeholders [27]. The new results [20,27] revealed, how the perception about the needs and application of CPS had been transformed in the period between the formulation of the ideas of the project and the start of its practical implementation.

The surveys provide input to the development of industry and research-oriented cross-domain study programs in Cyber-Physical Systems, namely:

- The surveys accumulate ideas for the formation of undergraduate and two-years practice-oriented master's programs with in-depth training in computer modeling of CPS in Belarusian and Ukrainian universities.

- The new educational programs will account for the requirements of research institutes, enterprises, and other employers regarding the qualifications of undergraduate and master-level students.

- The surveys detect the differences in the perceptions among representatives of Belarusian and Ukrainian stakeholders concerning the knowledge for the application of CPS and related modeling tools. All perceptions will be taken into consideration when developing new educational programs.

It should be borne in mind that the reform of the higher education system in Ukraine has not yet been completed. The reform provides close cooperation with leading European modern educational institutions. The CybPhys project envisages the involvement and implementation of modern methods and practices of European universities (RTU, KU Leuven, and UCY) into the educational process [28].

At the moment, for Ukraine and other European countries, innovations related to modern environmentally friendly, energy-efficient, and economical road transport are relevant [29-31]. It should be noted that this relevance is dictated by a complex range of factors-these are environmental, economic, social, and medical (e.g., the impact of exhaust gases on humans). The growing number of these types of vehicles requires a completely new approach to the development of infrastructure for their operation, maintenance, and repair. Charging stations and various power generating devices [32-34] should be part of this infrastructure. In this regard, CybPhys envisages the development of a joint innovative master level program of double degrees, "Electric Vehicles and Energy-Saving Technologies". Universities of Latvia and Ukraine, namely, RTU and KhNAHU, cooperate in the development of this educational program.

The present paper discusses ex-ante educational situations, the results obtained by the surveys [20,27], and its practical impact on the development of modern curricular for specialists in the area of CPS. The paper also analyses how the CybPhys project implements the principles of 
multidisciplinarity and T-shaped engineers' competencies in education programs for the students of Belarus and Ukraine. The novelty of this research is a contribution to the development of practically-oriented student-centered educational programs in the area of CPS for the universities of Belarus and Ukraine. This contribution is achieved relying on the research of industry's needs, the utilization of knowledge and experience of EU universities, the application of ICT based e-learning tools, and the integration of innovative pedagogical methods. This was the first representative survey that embraced different industries: oil; electricity; heating energy production; transport maintenance; mining and processing plant; cargo delivery; and other industries and research institutions located at three industrial regions of Ukraine, two regions of Belarus, and in the Belarusian capital, Minsk.

The paper is structured as follows. The authors summarize the materials and methods applied in this research in Section 2. The essence of the research offered in the paper is expressed in Section 3, which provides an analysis of the perception of Belarusian and Ukrainian employers, regional impact on the perception of Ukrainian employers, and evolution of the perception of Ukrainian employers concerning the fields of application of CPS and the tools to be applied. The main contribution of the research, general results, limitations, and possible directions for future work are discussed in Section 4 "Discussions and conclusions".

\section{Materials and Methods}

\subsection{The Approach of the Survey}

The questionnaire of an open-and-close type was developed and distributed among the stakeholders. Aspects such as the educational and social-cultural traditions of Belarus and Ukraine, as well as the experience gained while conducting multi-paradigm modeling of COST Action (Co-Operation in Science \& Technology) for Cyber-Physical Systems, were taken into account while being developed. EU partners contributed by experience obtained in the COST Action Multi-Paradigm Modelling for Cyber-Physical Systems [26,35].

The survey was conducted at the beginning stage of the project i.e., December 2019-March 2020. A total of 81 experts were interviewed, correlated with the specialization profiles of the CybPhys curricula and programs: 41 respondents from Belarus and 40 from Ukraine. The interviewees represent different industries, such as the oil industry, electrical and heating energy production, transport, maintenance, repair of vehicles, cargo delivery, etc. Scientific institutions of the Belarusian Academy of Sciences also participated in the survey. Some of the interviewees represent a particular branch of industry and an educational institution at the same time.

This survey among stakeholders should reveal and classify the most relevant competencies, related to particular areas of CPS. It was planned to apply these survey' data in the preparation of future CPS oriented curricula containing courses and laboratory workshops for bachelor and master students. The information was relevant in the field of computer physics, applied physics, transportation systems, logistics, mining industry, and electrical engineering.

The survey was implemented in the form of online and paper-based questionnaires in Russian, Ukrainian, and English languages. The participants were asked to provide some personal background information, which helped to interpret the answers:

- What are your professional activities (industry, education, research, or other)?

- Do you have previous or current experience with projects on Cyber-Physical Systems?

- Do you have experience in modeling of Cyber-Physical Systems or any other complex engineering systems?

- Describe briefly your experience and skills.

Consolidated data about the respondents' employment i.e., the names of the industry branches and the names of the enterprises were shown in Table 1. 
Table 1. Analysis of the background of responders from Belarus and Ukraine.

\begin{tabular}{|c|c|c|c|c|c|}
\hline \multicolumn{3}{|c|}{ Belarus } & \multicolumn{3}{|c|}{ Ukraine } \\
\hline Industry & $\begin{array}{l}\text { Names of the } \\
\text { Enterprises }\end{array}$ & $\begin{array}{l}\text { No. of } \\
\text { Resp. }\end{array}$ & Industry & Names of the Enterprises & $\begin{array}{l}\text { No. of } \\
\text { Resp. }\end{array}$ \\
\hline $\begin{array}{l}\text { IT and } \\
\text { software }\end{array}$ & $\begin{array}{c}\text { Andersen people, } \\
\text { Software AG, EPAM } \\
\text { Systems, IBA Gomel } \\
\text { Park }\end{array}$ & 10 & $\begin{array}{l}\text { IT and } \\
\text { software }\end{array}$ & $\begin{array}{c}\text { Institute of Software Systems } \\
\text { of NAS of Ukraine, Solty, } \\
\text { Astound Commerce Ukraine, } \\
\text { Beetroot }\end{array}$ & 4 \\
\hline Electronics & $\begin{array}{l}\text { PC Integral, STC } \\
\text { Belmicrosystems }\end{array}$ & 5 & Electronics & $\begin{array}{l}\text { State Research Institute for } \\
\text { Testing Certification of Arms } \\
\text { and Military Equipment, } \\
\text { Amateur Radio Association of } \\
\text { Ukraine, Chezara, Meredot } \\
\text { OÜ, HVD }\end{array}$ & 5 \\
\hline $\begin{array}{l}\text { Education } \\
\text { and science }\end{array}$ & $\begin{array}{l}\text { Belarusian National } \\
\text { Technical University, } \\
\text { BSU, }\end{array}$ & 5 & $\begin{array}{l}\text { Education } \\
\text { and science }\end{array}$ & $\begin{array}{l}\text { Chernihiv Small Academy of } \\
\text { Sciences of student youth, } \\
\text { Chernihiv National } \\
\text { Technological University, } \\
\text { Kharkiv National Automobile } \\
\text { University }\end{array}$ & 8 \\
\hline $\begin{array}{l}\text { Electrical } \\
\text { equipment }\end{array}$ & $\begin{array}{c}\text { Energo Met Systems, } \\
\text { Belaruskabel, Mozyr } \\
\text { Mechanical Engineering } \\
\text { Plant }\end{array}$ & 3 & $\begin{array}{l}\text { Electrical } \\
\text { equipment }\end{array}$ & $\begin{array}{c}\text { AHB Elektrik, } \\
\text { Elektroyuzmontaz }\end{array}$ & 4 \\
\hline $\begin{array}{l}\text { Materials } \\
\text { Science }\end{array}$ & $\begin{array}{l}\text { Scientific and Practical } \\
\text { Center of the NAS of } \\
\text { Belarus for Materials } \\
\text { Science }\end{array}$ & 4 & Transport & $\begin{array}{c}\text { Europe-auto, Gal-auto, } \\
\text { X-MOTORS, Elcars, } \\
\text { Mitsubishi Motors at Kharkiv } \\
\text { region, Transport and } \\
\text { Communications Department } \\
\text { of the Krivoy Rog City Council }\end{array}$ & 6 \\
\hline $\begin{array}{l}\text { Research and } \\
\text { Development }\end{array}$ & $\begin{array}{l}\text { Institutes of the National } \\
\text { Academy of Sciences }\end{array}$ & 2 & $\begin{array}{l}\text { Mining } \\
\text { industry }\end{array}$ & $\begin{array}{c}\text { Northern Mining and } \\
\text { Processing Plant, Institute of } \\
\text { Design for mining enterprises } \\
\text { Krivbassproekt }\end{array}$ & 4 \\
\hline Oil industry & $\begin{array}{c}\text { Mozyr Oil Refinery, } \\
\text { GomelTransoil Druzba, } \\
\text { Line operation } \\
\text { dispatcher station Mozyr, } \\
\text { Republican center for } \\
\text { hydrometeorology, } \\
\text { control of radioactive } \\
\text { contamination }\end{array}$ & 11 & Metallurgy & $\begin{array}{l}\text { Arcelor Mittal Kryvyi Rih, } \\
\text { Metinvest Digital LLC, } \\
\text { VISTGRUPP-Technical Center, } \\
\text { Central Mining and } \\
\text { Processing Plant, }\end{array}$ & 8 \\
\hline \multirow[t]{2}{*}{$\begin{array}{c}\text { Energy } \\
\text { production }\end{array}$} & $\begin{array}{l}\text { Mozyr Central Heating } \\
\text { and Power Plant }\end{array}$ & 1 & Legal services & Inforce LLC & 1 \\
\hline & Total: & fig & & Total: & 40 \\
\hline
\end{tabular}

Each of the Belarusian and Ukrainian project partners arranged a survey among their potential employers in order to represent particular industries and regions. A sufficiently large diversity among the interviewees was obtained. Generally, the number of persons that answered "yes" to the question "Do you have previous or current experience with projects on Cyber-Physical Systems?" did not differ between Belarusian and Ukrainian responders: 21 of 41 (Belarus) and 23 of 40 (Ukraine). The number of persons that answered "yes" to the question "Do you have experience in modeling of Cyber-Physical Systems or any other complex engineering systems?" also did not differ very much: 5 of 41 (Belarus) and 7 of 40 (Ukraine).

However, the answers to these same questions differed significantly between the groups of responders, presented by different project partners of the same country. For example, 4 people out of 20 surveyed by KhNAHU mentioned work experience on projects related to physical processes and CPS, and only 2 people out of 20 surveyed by KhNAHU mentioned experience in modeling 
Cyber-Physical Systems. This revealed that 4 and 2 of 20 interviewees of KhNAHU mentioned a relevant experience. For instance, the interviewees of CNTU revealed a totally different situation. All 10 interviewees mentioned work experience on projects related to CPS, and 4 people out of 10 mentioned experience in modeling CPS. Although both groups of responders represented Ukraine, their answers revealed a very different situation. It was worth noting that the KhNAHU related group of respondents represented mostly transportation enterprises, whereas the CNTU related group represented companies of the electronic and IT industries. A more detailed analysis of the answers was depicted in Section 3 "Results". Table 1 provided insight into the industries represented in the survey.

A set of questions was included in the survey. The content of the questions revealed the subjectively expected value of the respondents upon the suggested topics according to Rensis Likert's scale. Each question was treated from the point of (dis)agreement. Each position was evaluated from 1 to 5 , where 1 means "not relevant", 5 means "very relevant", but 3 expresses the neutral attitude of the respondent to the subject matter.

The questions in the survey form were grouped into three categories: Field of application of Cyber-Physical Systems; Design and modeling of Cyber-Physical Systems; Software development (see Table 2). Table 2 showed, for each category, a number of topics indicating the importance of the category in the considered topic.

Table 2. The categories and topics of questions in the survey form.

\begin{tabular}{|c|c|c|c|}
\hline No. & The Category & Description of the Topic & Scale of Evaluation \\
\hline 1 & $\begin{array}{l}\text { Field of application of } \\
\text { Cyber-Physical Systems }\end{array}$ & $\begin{array}{c}\text { Car industry, Building automation, } \\
\text { Smart City, Management of production } \\
\text { processes, Transport system, Energy } \\
\text { production, Robotics, Transfer processes } \\
\text { in nano-electronics, Other areas (name } \\
\text { which) }\end{array}$ & 5-point scale \\
\hline 2 & $\begin{array}{l}\text { Design and modeling of } \\
\text { Cyber-Physical Systems } \\
\text { (statistics systems, } \\
\text { modeling tools) }\end{array}$ & $\begin{array}{l}\text { Mechatronics (Liquid, Bio-Systems, } \\
\text { Robotics, Gas and hydrodynamics, } \\
\text { Other industry). Tools and languages } \\
\text { (Purely statistical systems: SPSS, } \\
\text { SimaPro). Monte-Carlo. Agents-Based. } \\
\text { Industrial design (Matlab/Simulink, } \\
\text { Modelica, COMSOL Multiphysics, } \\
\text { Visual-CFD, ANSYS,) Other (name } \\
\text { which) }\end{array}$ & 5-point scale \\
\hline 3 & Software development & $\begin{array}{l}\text { Resource-intensive modeling, } \\
\text { Interpreted Languages, The } \\
\text { development and utilization Domain, } \\
\text { Specific Languages (UML, SenML, etc.), } \\
\text { Automated test generation, Formal } \\
\text { analysis, Convenience and simplicity, } \\
\text { Empirical analysis }\end{array}$ & 5-point scale \\
\hline
\end{tabular}

In the following chapters, answers to the questions in Table 2 are analyzed by considering the separate topics. Comparisons between different opinions in different countries and by responders to different universities of one single country were made. We also analyzed, how the perception of industry representatives concerning the application of CPS evolved between the two surveys conducted in 2018 and 2020.

\subsection{Analysis for Confidence Intervals of Two Distributions of Ukrainian and Belarusian Survey Results}

In order to evaluate the significance of the survey results, we used the t-distribution (Student's $\mathrm{t}$-distribution). This $\mathrm{t}$-distribution was used to estimate population parameters when the sample size was small and when the population variance was unknown. The t-distribution provided a good way 
to perform sample tests on the mean when the population variance was not known, provided the population was normal or the sample was sufficiently large so that the Central Limit Theorem applies. Furthermore, the t-distribution provided good results, even when the population was not normal and the sample was small. It was, however, important that the sample data was reasonably symmetrically distributed around the sample mean.

Excel was used in order to calculate the confidence interval for the $\mathrm{t}$-distribution. CONFIDENCE.T $(\alpha, \mathrm{s}, \mathrm{n})=\mathrm{k}$ such that $(\bar{x}-\mathrm{k}, \bar{x}+\mathrm{k})$ is the confidence interval of the sample mean. Here, $\mathrm{n}$ is the sample size, $\mathrm{s}$ is the sample standard deviation, and $1-\alpha$ is the confidence expressed in \%.

To evaluate the results from the Belarusian partners dealing with the category "field of Cyber-Physical Systems application" related to the topic "car industry", we calculated CONFIDENCE.T $(0.05,0.8533,41)=0.2693$. A $95 \%$ confidence interval of the sample mean equaled (3.8770, 4.4157). Additionally, the statistics data from the Ukrainian partners dealing with the category "Field of Cyber-Physical Systems application" related to the same topic "car industry", demonstrated CONFIDENCE.T $(0.05,0.9323,40)=0.2982$. A $95 \%$ confidence interval of the sample mean equaled (4.1518, 4.7482).

Notice that the Ukrainian mean of 4.4500 lied outside the Belarusian confidence interval of (3.8770, 4.4157) and that the Belarusian mean of 4.1463 lied outside the Ukrainian confidence interval of (4.1518, 4.7482). This revealed the Belarusian and Ukrainian responders had a somewhat different opinion concerning the importance of CPS in the car industry.

However, in the present paragraph, we did not evaluate the confidence intervals of the means for all topics of the "field of Cyber-Physical Systems application". In Section 3, we have analyzed and compared evaluation marks put by Belarusian and Ukrainian representatives, to be aware of the significance of our conclusions. Thus, it was possible to calculate the confidence intervals for any topic on a question and to expect that $95 \%$ of them would contain the population mean.

\section{Results}

\subsection{Analysis of Perception of Belarusian and Ukrainian Employers}

In Table 3, we summarized the results from the survey forms related to the perception of responders about the fields of Cyber-Physical Systems applications.

We calculated the average mean of Ukrainian and Belarusian responders: the average mean of Ukrainian responders is 4.2719 , and the average mean of Belarusian responders is 4.2877 . The difference between the average means of Ukrainian and Belarusian responders is +0.0158 .

The survey showed that the difference between the average means of the marks put by Belarusian and Ukrainian representatives was only +0.0158 . The global perception of Belarusian representatives about the fields of application of CPS looked more optimistic, i.e., somewhat higher means were obtained. However, opinions about the opportunities to apply CPS in particular fields differed greatly e.g., Belarusian representatives were more optimistic about "complex physical systems" (the difference of the means is $+11.1 \%$ ), but much less optimistic about "transportation systems" $(-10.0 \%)$. The latter could be explained by the fact that none of the Belarusian responders represented the transport industry. A commonality of views was expressed by the fact that the representatives of both countries recognized "robotics" as the most real field of application of CPS.

In Table 4, we summarized the results from survey forms related to the perception of responders about the category "design and modeling of Cyber-Physical Systems". 
Table 3. Comparison of the answers of Belarusian and Ukrainian representatives about the fields of Cyber-Physical Systems applications.

\begin{tabular}{cccccccccccc}
\hline No. & The Topic & \multicolumn{4}{c}{ Ukraine } & \multicolumn{3}{c}{ Belarus } & \multicolumn{2}{c}{ Differ.\% } & $\begin{array}{c}\text { Differ. } \\
\text { Rank }\end{array}$ \\
\hline & & N & Mean & SD & Rank & N & Mean & SD & Rank & \\
\hline 1 & Car industry & 40 & 4.4500 & 0.9323 & 4 & 41 & 4.1463 & 0.8533 & 7 & -7.1 & 5 \\
\hline 2 & $\begin{array}{c}\text { Building } \\
\text { automation }\end{array}$ & 40 & 3.4000 & 1.1277 & 8 & 41 & 4.1707 & 0.8917 & 6 & 18.0 & 1 \\
\hline 3 & Smart City & 40 & 4.6000 & 0.8102 & 3 & 41 & 4.4390 & 0.8674 & 3 & -3.7 & 8 \\
\hline 4 & $\begin{array}{c}\text { Management } \\
\text { of production } \\
\text { processes }\end{array}$ & 40 & 4.2750 & 1.0619 & 6 & 41 & 4.5122 & 0.6373 & 2 & 5.5 & 6 \\
\hline 5 & $\begin{array}{c}\text { Transportation } \\
\text { systems }\end{array}$ & 40 & 4.6000 & 0.6325 & 2 & 41 & 4.1707 & 0.8632 & 5 & -10.0 & 3 \\
\hline 6 & $\begin{array}{c}\text { Energy } \\
\text { production }\end{array}$ & 40 & 4.3500 & 0.8022 & 5 & 41 & 4.0488 & 0.8646 & 8 & -7.0 & 4 \\
\hline 7 & Robotics & 40 & 4.6250 & 0.7742 & 1 & 41 & 4.4634 & 0.6744 & 1 & -3.7 & 7 \\
\hline 8 & $\begin{array}{c}\text { Complex } \\
\text { physical } \\
\text { systems }\end{array}$ & 40 & 3.8750 & 1.2234 & 8 & 41 & 4.3500 & 0.7355 & 4 & 11.1 & 2 \\
\hline
\end{tabular}

Table 4. Comparison of the answers of Belarusian and Ukrainian representatives about the category Design and modeling of Cyber-Physical Systems (statistics systems, modeling tools).

\begin{tabular}{cccccccccccc}
\hline No & The Topic & \multicolumn{4}{c}{ Ukraine } & \multicolumn{3}{c}{ Belarus } & \multicolumn{2}{c}{ Diff.\% } & $\begin{array}{c}\text { Diff. } \\
\text { Rank }\end{array}$ \\
\hline & & N & Mean & SD & Rank & N & Mean & SD & Rank & \\
\hline $\begin{array}{c}\text { Purely } \\
1\end{array}$ & $\begin{array}{c}\text { statistical } \\
\text { systems }\end{array}$ & 23 & 2.6957 & 0.9740 & 9 & 31 & 3.7667 & 0.9353 & 6 & 30.6 & 2 \\
\hline 2 & SPSS & 26 & 2.3846 & 1.0983 & 11 & 38 & 3.1053 & 0.7637 & 8 & 20.5 & 4 \\
\hline 3 & SimaPro & 29 & 2.9655 & 1.0171 & 7 & 39 & 2.5128 & 0.9966 & 10 & -12.9 & 7 \\
\hline 4 & Monte-Carlo & 29 & 2.7586 & 1.2146 & 8 & 41 & 3.9756 & 1.1935 & 4 & 34.7 & 1 \\
\hline 5 & Agents-Based & 25 & 2.6400 & 1.1136 & 10 & 37 & 2.4324 & 1.0419 & 11 & -5.9 & 9 \\
\hline 6 & $\begin{array}{c}\text { Industrial } \\
\text { design }\end{array}$ & 20 & 3.5455 & 1.0568 & 3 & 30 & 4.0333 & 1.0662 & 3 & 13.9 & 5 \\
\hline 7 & Matlab/Simulink & 29 & 4.2759 & 1.1306 & 1 & 30 & 4.1842 & 0.7660 & 1 & -2.6 & 11 \\
\hline 8 & Modelica & 36 & 3.5000 & 1.2536 & 4 & 38 & 3.0789 & 1.0496 & 9 & -12.0 & 8 \\
\hline 9 & $\begin{array}{c}\text { COMSOL } \\
\text { Multiphysics }\end{array}$ & 27 & 3.4444 & 1.1875 & 5 & 38 & 3.9211 & 1.1713 & 5 & 13.6 & 6 \\
\hline 10 & Visual-CFD & 28 & 3.1071 & 1.2864 & 6 & 38 & 4.1000 & 1.0573 & 2 & 28.3 & 3 \\
\hline 11 & ANSYS & 34 & 3.5758 & 1.0009 & 2 & 39 & 3.3846 & 1.0161 & 7 & -5.4 & 10 \\
\hline
\end{tabular}

The average mean of Ukrainian responders calculated in Table 4 was 3.1721, but the average mean of Belarusian responders was 3.4995. Therefore, the difference between the average means of Ukrainian and Belarusian responders was +0.3274 (i.e., $10.3 \%$ ).

The difference between the average means of the marks put by Belarusian and Ukrainian representatives about the category "design and modeling of Cyber-Physical Systems" was +0.3274 , i.e., $10.3 \%$. This meant that Belarusian representatives generally were more optimistic about statistics 
systems and modeling tools for CPS. This difference was more significant in comparison with the evaluation application fields of CPS (see Table 3). Respondents of both countries shared positive views about the application of design and modeling tools such as Matlab/Simulink and industrial design tools. They both ranked them in the first and third place respectively. Notice, however, the perception concerning the application of Monte-Carlo and purely statistical systems differed significantly $(+34.7 \%$ and $+30.6 \%$ ).

The comparison of the answers justified our assumption made in Section 1, i.e., the perceptions of industry representatives concerning the application of design and modeling tools depend, to a large extent, on the region.

In Table 5, we summarized the results from survey forms related to the perception of the responders about the category "Software development tools".

Table 5. Comparison of the answers of Belarusian and Ukrainian representatives about the software development tools.

\begin{tabular}{|c|c|c|c|c|c|c|c|c|c|c|c|}
\hline \multirow[t]{2}{*}{ No. } & \multirow[t]{2}{*}{ The Topic } & \multicolumn{4}{|c|}{ Ukraine } & \multicolumn{4}{|c|}{ Belarus } & \multirow[t]{2}{*}{ Diff.\% } & \multirow[t]{2}{*}{$\begin{array}{l}\text { Diff. } \\
\text { Rank }\end{array}$} \\
\hline & & $\mathbf{N}$ & Mean & SD & Rank & $\mathbf{N}$ & Mean & SD & Rank & & \\
\hline 1 & $\begin{array}{l}\text { Resource-intensive } \\
\text { modeling }\end{array}$ & 39 & 4.3333 & 0.8057 & 2 & 39 & 4.1538 & 0.8747 & 2 & 4.5 & 4 \\
\hline 2 & $\begin{array}{l}\text { Interpreted } \\
\text { Languages }\end{array}$ & 38 & 3.6216 & 1.3406 & 6 & 39 & 3.8718 & 0.9782 & 5 & -6.3 & 3 \\
\hline 3 & $\begin{array}{l}\text { The development } \\
\text { and utilization of } \\
\text { Domain-Specific } \\
\text { Languages (UML, } \\
\text { SenML, etc.) }\end{array}$ & 27 & 4.3810 & 0.7400 & 1 & 10 & 4.3750 & 0.5175 & 1 & 0.1 & 7 \\
\hline 4 & $\begin{array}{l}\text { Automated test } \\
\text { generation }\end{array}$ & 39 & 4.0513 & 0.9162 & 4 & 40 & 3.8974 & 0.9946 & 4 & 3.9 & 5 \\
\hline 5 & Formal analysis & 39 & 3.3846 & 1.2899 & 7 & 39 & 3.8158 & 0.9545 & 7 & -10.8 & 1 \\
\hline 6 & $\begin{array}{l}\text { Convenience and } \\
\text { simplicity }\end{array}$ & 39 & 4.2821 & 0.9162 & 3 & 39 & 3.9211 & 1.1713 & 3 & 9.0 & 2 \\
\hline 7 & Empirical analysis & 40 & 3.8750 & 0.9920 & 5 & 39 & 3.8421 & 1.1035 & 6 & 0.8 & 6 \\
\hline
\end{tabular}

The average mean of Ukrainian responders calculated in Table 5 was 3.9898, but the average mean of Belarusian responders was 3.9824. Therefore, the difference between the average means of Ukrainian and Belarusian responders was -0.0074 (i.e., $-0.19 \%$ ).

The difference between the average means of the marks put by Belarusian and Ukrainian representatives about the category software development tools was very small: -0.0074 , i.e., $-0.19 \%$. This meant that, in general, the perceptions of Ukrainian and Belarusian respondents did not differ. Notice, however, that different answers were received when considering different topics. For example, the perception of Ukrainian and Belarusian respondents concerning the application of formal analysis showed a mean difference of $-10.8 \%$. When considering Interpreted Languages, the means difference is $-6.3 \%$.

Although there were differences between the answers from Belarusian and Ukrainian representatives, the rankings of the topics in Table 5 were very similar. In both countries, the topic "the development and utilization of Domain-Specific Languages" had the highest ranking, the topic "resource-intensive modeling" obtained the second place, the topic "convenience and simplicity" obtained the third place, and the topic "automated test generation" had the fourth place.

\subsection{Regional Impact on Perception of Ukrainian Employers}

The perceptions of Ukrainian and Belarusian respondents about the application of the software development tools, in general, almost did not differ. It was, however, interesting to know how the 
regional factor impacts on the answers of the respondents. In Table 6, we summarized the results from the survey forms related to the perception of the responders of two Ukrainian universities about the category "Software development tools". The universities KhNAHU and CNTU were allocated in geographically and socioeconomically different regions.

Table 6. Comparison between Ukrainian universities Kharkiv National Automobile and Highway University (KhNAHU) and Chernihiv National Technological University (CNTU) about the Software development tools.

\begin{tabular}{|c|c|c|c|c|c|c|c|c|c|c|c|}
\hline \multicolumn{6}{|c|}{ Kharkiv National Automobile and Highway University } & \multicolumn{4}{|c|}{$\begin{array}{l}\text { Chernihiv National } \\
\text { Technological University }\end{array}$} & \multirow[t]{2}{*}{ Diff.\% } & \multirow[t]{2}{*}{$\begin{array}{l}\text { Diff. } \\
\text { Rank }\end{array}$} \\
\hline No & The Topic & $\mathbf{N}$ & Mean & SD & Rank & $\mathbf{N}$ & Mean & SD & Rank & & \\
\hline 1 & $\begin{array}{l}\text { Resource-intensive } \\
\text { modeling }\end{array}$ & 20 & 4.0500 & 0.8870 & 3 & 9 & 4.2222 & 0.6667 & 2 & 4.9 & 6 \\
\hline 2 & $\begin{array}{l}\text { Interpreted } \\
\text { Languages }\end{array}$ & 19 & 2.7895 & 1.2283 & 6 & 8 & 4.2500 & 0.8864 & 1 & 41.7 & 2 \\
\hline 3 & $\begin{array}{l}\text { The development } \\
\text { and utilization of } \\
\text { Domain-Specific } \\
\text { Languages (UML, } \\
\text { SenML, etc.) }\end{array}$ & 12 & 4.4167 & 0.5149 & 1 & 5 & 3.8000 & 1.0954 & 7 & -17.6 & 3 \\
\hline 4 & $\begin{array}{l}\text { Automated test } \\
\text { generation }\end{array}$ & 20 & 3.7000 & 0.7327 & 4 & 9 & 4.2222 & 1.0929 & 3 & 14.9 & 4 \\
\hline 5 & Formal analysis & 20 & 2.4500 & 0.8256 & 7 & 9 & 4.1111 & 0.9280 & 4 & 47.5 & 1 \\
\hline 6 & $\begin{array}{l}\text { Convenience and } \\
\text { simplicity }\end{array}$ & 20 & 4.1500 & 1.0400 & 2 & 9 & 4.0000 & 0.8660 & 5 & -4.3 & 7 \\
\hline 7 & Empirical analysis & 20 & 3.4500 & 0.9987 & 5 & 10 & 3.9000 & 0.8756 & 6 & 12.9 & 5 \\
\hline
\end{tabular}

The average mean of KhNAHU responders calculated in Table 6 was 3.5723, but the average mean of CNTU responders was 4.0722. Therefore, the difference between the average means of KhNAHU and CNTU responders was 0.4999 (i.e., $14 \%$ ).

A comparison of the answers of responders from two Ukrainian universities, KhNAHU and CNTU (see Table 6), revealed divergent views about the importance of software development tools. Although CNTU responders generally evaluated the considered tools $14 \%$ higher than the KHNAHU responders, they were less optimistic about the application of "the development and utilization of Domain-Specific Languages" (-17.6\%) and "convenience and simplicity" $(-4.3 \%)$. A comparison of the ranking provided by both samples of responders approximately showed a similar view about "resource-intensive modeling" (the rankings equal 3rd and 2nd) and about "empirical analysis" (the rankings equal 5th and 6th). The divergent evaluation could be explained by the fact that the responders provided by KhNAHU mainly represented transport services, transport maintenance, and other fields related to the transport sector, whereas the background of CNTU responders was mainly electronics, electrical engineering, and software development.

These examples revealed that the means of the marks provided by two separate university-linked Ukrainian groups of respondents were larger than the global differences between Belarusian and Ukrainian respondents. This fact raised an important question to the CybPhyis team. How is it possible to deal with industry requirements which diverge when considering different countries, regions, and enterprises? Could these differences be appreciated by appropriate curricular design and the development of flexible teaching and learning methods? In Section 4, we discuss the ways the CybPhys team plans to resolve this issue.

\subsection{Evolution of the Perception of Ukrainian Employers}

The idea to develop industry-oriented curricula for different areas of application of Cyber-Physical Systems came to the initiators of the CybPhys project in 2017. This explains why the first survey of Ukrainian industry' representatives was conducted in the year 2018. Since the situation of the 
labor market was changing, it was important to be aware of how the perceptions of the industry representatives were evolving. This consideration reveals why the results of two surveys of Ukrainian industry' representatives, conducted in the years 2018 and 2020, respectively, are compared in this chapter.

Twenty-four respondents participated in a survey that was conducted by KNU and KhNAHU in December 2018 (CNTU joined to CybPhys consortium later, in 2019). The professional backgrounds of the responders included: transport, maintenance, repair of vehicles and cargo delivery (14 persons); education and research in the field of automobile transport (7 persons); software development ( 2 persons); electrical equipment (1 person). Experience in work on projects related to CPS denoted 10 people out of 24. Experience in modeling Cyber-Physical Systems made up 6 people out of 24 . Forty respondents participated in the survey conducted in 2020; their backgrounds and experiences were described in Table 1.

In order to develop a confidence in the comparison of the two surveys, we determined whether there are significant differences between the respondent's perceptions of the two surveys. Our null hypothesis, H0, equaled $\mu 1-\mu 2=0$ i.e., there was no difference between the two surveys. We calculated descriptive statistics on the topics of both surveys and for a demonstration example the topic "building automation" was selected. Due to the lack of place, the calculations of the descriptive statistics were omitted in this paper.

The calculated variances were relatively similar (1.2718 and 1.2391), so the t-Test (Two-Sample Assuming Equal Variances) data analysis tool could be used to test the null hypothesis. The results showed $t_{\text {obs }}=3.968>1.999=t_{\text {crit }}$ (or $p$-value $\left.=0.00019<0.05=\alpha\right)$, therefore, we rejected the null hypothesis. We concluded that there were significant differences between the results of the two surveys. In fact, the perception of respondents in the year 2020 was much more favorable, concerning the application of CPS, than it was in 2018.

Comparison of the answers in the year 2018 and the year 2020 (see Table 7) revealed that the general perception of Ukrainian industry representatives about the fields of application of CPS became more optimistic, as the difference between the average means equaled +0.5271 , i.e., $+14.1 \%$. The growth of perception was especially noticed in relation to "complex physical systems" $(+39.2 \%)$, "building automation" (+32.8\%), and "management of production processes" $(+23.3 \%)$. The topic "robotics" was still recognized as the most important field of application of CPS (2nd place in 2018 and 1st in 2020). It was worth noting that the participation of CNTU in 2020 in some way impacted the results of the survey since, in general, the representatives selected by CNTU had work experience on projects related to CPS. Additionally, the growth of the positive perception was also partially achieved thanks to the promotion of the CybPhys project targets among industrial partners.

Table 7. Comparison between the two surveys of Ukrainian industries conducted in 2018 and 2020.

\begin{tabular}{|c|c|c|c|c|c|c|c|c|c|c|c|}
\hline \multirow[t]{2}{*}{ No } & \multirow[t]{2}{*}{ The Topic } & \multicolumn{4}{|c|}{ Year 2018} & \multicolumn{4}{|c|}{ Year 2020} & \multirow[t]{2}{*}{ Diff.\% } & \multirow{2}{*}{$\begin{array}{l}\text { Diff. } \\
\text { Rank }\end{array}$} \\
\hline & & $\mathbf{N}$ & Mean & SD & Rank & $\mathbf{N}$ & Mean & SD & Rank & & \\
\hline 1 & Car industry & 24 & 4.7917 & 0.4149 & 1 & 41 & 4.1463 & 0.8533 & 7 & -9.7 & 6 \\
\hline 2 & Building automation & 24 & 2.2500 & 1.1132 & 8 & 41 & 4.1707 & 0.8917 & 6 & 32.8 & 2 \\
\hline 3 & Smart City & 24 & 3.8750 & 1.0759 & 4 & 41 & 4.4390 & 0.8674 & 3 & 20.7 & 4 \\
\hline 4 & $\begin{array}{l}\text { Management of } \\
\text { production processes }\end{array}$ & 24 & 3.4583 & 0.8836 & 6 & 41 & 4.5122 & 0.6373 & 2 & 23.3 & 3 \\
\hline 5 & Transportation systems & 24 & 4.7083 & 0.5500 & 3 & 41 & 4.1707 & 0.8632 & 5 & -3.1 & 7 \\
\hline 6 & Energy production & 24 & 3.8333 & 0.8681 & 5 & 41 & 4.0488 & 0.8646 & 8 & 14.7 & 5 \\
\hline 7 & Robotics & 24 & 4.5417 & 0.6580 & 2 & 41 & 4.4634 & 0.6744 & 1 & 2.3 & 8 \\
\hline 8 & $\begin{array}{l}\text { Complex physical } \\
\text { systems }\end{array}$ & 24 & 2.5000 & 0.8341 & 7 & 41 & 4.3500 & 0.7355 & 4 & 39.2 & 1 \\
\hline
\end{tabular}

The average mean obtained in the year 2018 equaled 3.7448, but the average mean obtained in the year 2020 equaled 4.2719 , as shown in Table 7. Therefore, the difference between the average means of the year 2018 and year 2020 responders was +0.5271 (i.e., $+14.1 \%$ ). This revealed an increasing interest in CPS based applications. 


\section{Discussions and Conclusions}

As a start, we put forward the hypothesis that the educational situation, the training opportunities, the situation of the labor market, and the general economic development are related to each other and vary depending on the region. The results of the study discussed in the present paper confirm our hypothesis, e.g., the differences between the answers provided by the Ukrainian universities KhNAHU and CNTU, allocated in different regions of the same country, were more significant than the deviations between the global evaluation marks obtained from all Belarusian and all Ukrainian respondents.

A country's broad view on the background of participants did not reveal significant differences concerning their experience related to participation in the CPS projects and their competences concerning the modeling of CPS. However, the results of the study support the hypothesis that different groups of respondents linked with different job positions, different industry branches, and different regions provide different emphases. The deeper analysis displays an important commonality in views of representatives of both countries concerning some particular fields of application e.g., "Robotics". At the same time, it reveals large deviations concerning particular fields, e.g., "Transportation systems" where Ukrainian respondents are definitely more interested, i.e., $+10 \%$.

One of the research targets is the accumulation of ideas useful for the formation of undergraduate and two-years practice-oriented master's programs at Belarusian and Ukrainian universities, with in-depth training in computer modeling of CPS. In order to increase the synergy of the partners, we suggest developing a system of interconnected didactic tools to teach students. More precisely, nine e-books for students and teachers will be developed. These nine e-books, which will be written in English and later translated to national languages, represent topics like:

1. Bringing innovations to the market.

2. Mathematical modelling of mechatronics systems.

3. Model-oriented control in intelligent manufacturing systems.

4. Modern mathematical physics: fundamentals and application.

5. High-performance scientific computing and data analysis.

6. Cyber-Physical Systems modelling and simulation.

7. Cyber-Physical Systems for clean transportation.

8. Control methods for critical infrastructure and IoT interdependencies analysis.

9. Computer modelling of physical processes.

These nine e-books will be used by the Belarusian and Ukrainian partners to develop fifty new courses at the six participating universities.

For example, the content of the e-book "Cyber-Physical Systems for clean transportation" takes into account the areas of application of CPS, such as car industries and transportation systems. This e-book reveals topics devoted to electric vehicles, fuel cell cars, hybrid vehicles, charging batteries, impact of electric cars on the power grid, etc.

Transdisciplinary and T-shape skills approaches will be implemented in the e-books and other training and teaching materials. Application of methods like engineering reasoning, problem-solving (included modeling and qualitative analysis), studying the interaction of the CPS systems, etc., will be revealed in the e-books. For example, the e-book "Bringing innovations to the market" will provide the students with particular expertise, such as prototypes software versus hardware, project management, commercialization, e-commerce, and digital marketing, etc.

In order to increase the synergy of the CybPhys partners, an innovative ICT based teaching and learning environment will be developed. Additionally, distance learning and teaching methodologies, focusing on the application of ICT tools, will be developed. The implementation has been started in two ways: the first is the creation of an Electronic Library at virtual environments for distance learning and virtual mobility on the base of the Moodle platform. This includes elaborating of e-books, digital writing and publishing facilities, development of learning and teaching methodologies, and pedagogical 
approaches for use of ICT. The second ICT tool, a Sharing Modeling and Simulation Environment platform, will be developed for online and virtual laboratories for modeling and simulation of CPS. Furthermore, methodologies and teaching materials for implementing distance and virtual laboratories will be created.

To form a T-shaped competence model with an expert who will have developed mind and leadership skills and to introduce the elements of Advance Education [13], the techniques of modeling and simulating education should be used. These teaching techniques will allow the students to face the challenges which are typical for real professional activity. The students will get to know how to apply theoretical knowledge practically, how to find the appropriate solutions to any problem and to develop individual and effective strategies, and how to form psychological readiness and professional Me-concept.

Mental capacity cards, some parts of the "Turned over class" technology, "immersion" lectures, "paradox" lectures, and binary lectures are offered to be introduced into practical training of students. The following methods of training are suggested i.e., methods of situational exercise, case study method, shade/combined/individual/back-and-forth brainstorm, brain-rating, method of inversion, method of dissolution for dead-locked situations, construction office, analytics and creative project, situational labyrinth, etc.

According to the project, the plan elements of developed courses will be tested by professors and student groups. For this purpose, several "training schools" will be conducted in Belarusian, Ukrainian, and European partnered universities. Feedback from the training schools will be collected and evaluated in order to make adjustments in the methods of teaching and content of the courses at the development stage, before finalizing formal accreditation of the courses and study programs.

In order to validate the CybPhys approach, we intend to arrange research at the end of the project (leading to a post-ante report), aiming to measure the degree of satisfaction of the representatives of the industry about the courses and programs developed during the Erasmus+ project.

The restrictions of the research:

- The questions of the survey form are derived from the experience acquired in the COST Action [35] that focused on the needs and perceptions of EU universities and companies. Probably, the needs of two non-EU countries differ from European ones. Therefore, the recommendations and suggestions expressed by respondents in Belarus and Ukraine will be analyzed and utilized when the post-ante survey of the stakeholders is prepared.

- This research does not aim to present an exhaustive view of all industry branches which deal with CPS in the countries. The research aims to produce a decent contribution to the development of a novel, industry-oriented curriculum adapted to the needs of Belarusian and Ukrainian project stakeholders.

Starting the project CybPhys, the partner universities defined the educational courses and programs to be developed in the project. This research provided an opportunity to comprehend the requirements of research institutes, enterprises, and other employers regarding the qualifications of undergraduates and master-level students.

Author Contributions: Conceptualization, A.Z. and J.P.; methodology, A.Z. and N.K.; formal analysis, A.Z.; investigation, A.Z., J.P. and N.K.; data curation, V.K., S.H., A.H., T.P.; writing-original draft preparation, A.Z., A.H. and J.P.; writing-review and editing, A.Z. and L.R.; visualization, A.Z.; supervision, L.R. All authors have read and agreed to the published version of the manuscript.

Funding: This research received no external funding.

Acknowledgments: This publication was developed with the support of "Development of practically-oriented student-centered education in the field of modeling of Cyber-Physical Systems" (CybPhys) 609557-EPP-1-2019-1-LV-EPPKA2-CBHE-JP-ERASMUS+ CBHE.

Conflicts of Interest: The authors declare no conflict of interest. 


\section{References}

1. Zabasta, A.; Kunicina, N.; Peuteman, J.; De Craemer, R.; Fedotov, A. Development of industry-oriented, student-centred master-level education in the field of physical sciences in Belarus. In Proceedings of the EDULEARN18 Conference, Palma, Mallorca, Spain, 2-4 July 2018; pp. 3641-3648. [CrossRef]

2. Krämer, B.J. Evolution of Cyber-Physical Systems: A Brief Review. In Applied Cyber-Physical Systems; Suh, S.C., Tanik, U.J., Carbone, J.N., Eroglu, A., Eds.; Springer: London, UK, 2014; pp. 1-3. [CrossRef]

3. EPoSS. Strategic Research Agenda of the European Technology Platform on Smart Systems Integration; EPoSS e.V.: Berlin, Germany, 2017; pp. 1-76.

4. Strategic Research Agenda for Electronic Components and Systems 2020. Prepared on Behalf of AENEAS, ARTEMIS Industry Association; pp. 1-368. Available online: https://aeneas-office.org/wp-content/uploads/ 2020/07/ECS-SRA2020_L.pdf (accessed on 24 September 2020).

5. ITEA/ARTEMISIA. High-Level Vision 2030. Available online: https://artemis-ia.eu/publication/download/ 907-vision-2030.pdf (accessed on 24 September 2020).

6. ECSEL MASRIA 2017. Available online: https://www.smart-systems-integration.org/publication/ecselmasria-2017 (accessed on 24 September 2020).

7. Törngren, M.; Paul, T.; Grogan, P.T. How to deal with the complexity of future cyber-physical systems? Designs 2018, 2, 40. [CrossRef]

8. Tan, Y.; Yang, W.; Yoshida, K.; Takakuwa, S. Application of IoT-aided simulation to manufacturing systems in cyber-physical system. Machines 2019, 7, 2. [CrossRef]

9. Rehman, S.; Gruhn, V. An effective security requirements engineering framework for cyber-physical systems. Technologies 2018, 6, 65. [CrossRef]

10. Brazell, J.B. The Need for a Transdiciplinary Approach to Security of Cyber Physical Infrastructure. In Applied Cyber-Physical Systems; Suh, S.C., Tanik, U.J., Carbone, J.N., Eroglu, A., Eds.; Springer: London, UK, 2014; pp. 5-14. [CrossRef]

11. Törngren, M.; Herzog, E. Towards Integration of CPS and Systems Engineering in Education. In Proceedings of the WESE Workshop on Embedded and Cyber-Physical Systems Education, Pittsburgh, PA, USA, 6 October 2016. [CrossRef]

12. Kunicina, N.; Zabasta, A.; Ziravecka, A.; Gaile-Sarkane, E.; Ribickis, L. Industry-academia cooperation support for creative thinking skills strengthening of undergraduates' students in electrical engineering. In Proceedings of the 2018 IEEE Global Engineering Education Conference (EDUCON), Santa Cruz de Tenerife, Spain, 17-20 April 2018; pp. 863-871. [CrossRef]

13. Gitelman, L.D.; Sandler, D.G.; Gavrilova, T.B.; Kozhevnikov, M.V. Complex systems management competency for technology modernization. Int. J. Des. Nat. Ecodyn. 2017, 12, 525-537. [CrossRef]

14. Kodama, F. Learning mode and strategic concept for the 4 th industrial revolution. J. Open Innov. Technol. Market Complex. 2018, 4, 32. [CrossRef]

15. Johnson, C.; Tilt, J.H.; Ries, P.D.; Shindler, B. Continuing professional education for green infrastructure: Fostering collaboration through interdisciplinary trainings. Urban For. Urban Green. 2019, 41, $283-291$. [CrossRef]

16. Stachová, K.; Papula, J.; Stacho, Z.; Kohnová, L. External partnerships in employee education and development as the key to facing industry 4.0 challenges. Sustainability 2019, 11, 345. [CrossRef]

17. Mourtzis, D.; Vlachou, E.; Dimitrakopoulos, G.; Zogopoulosa, V. Cyber-physical systems and education 4.0-the teaching factory 4.0 concept. Procedia Manuf. 2018, 23, 129-134. [CrossRef]

18. Gitelman, L.; Kozhevnikov, M.; Ryzhuk, O. Advance management education for power-engineering and industry of the future. Sustainability 2019, 11, 5930. [CrossRef]

19. Development of Practically-Oriented Student-Centred Education in the Field of Modelling of Cyber-Physical Systems (CybPhys), 609557-EPP-1-2019-1-LV-EPPKA2-CBHE-JP_ERASMUS+ CBHE, Detailed Description of the Project. Available online: https://cybphys.rtu.lv/ (accessed on 29 July 2020).

20. Zabasta, A.; Zhiravetska, A. Ex Ante Evaluation Report, Deliverable 1 of the Erasmus+ Project Development of Practically-Oriented Student-Centred Education in the Field of Modelling of Cyber-Physical Systems. Available online: https://cybphys.rtu.lv/ (accessed on 29 July 2020). 
21. Zabasta, A.; Kunicina, N.; Prylutskyy, Y.; Peuteman, J.; Fedotov, A.K.; Fedotov, A.S. Development of Industry Oriented Curricular on Cyber Physical Systems for Belarusian and Ukrainian Universities. In Proceedings of the 6th IEEE Workshop on Advances in Information, Electronic and Electrical Engineering, AIEEE, Vilnius, Lithuania, 8-10 November 2018; pp. 1-6. [CrossRef]

22. Zintgraff, C.; Wilson Green, C.; Carbone, J.N. A Regional and Transdiciplinary Approach to Educating Secondary and College Students in Cyber-Physical Systems. In Applied Cyber-Physical Systems; Suh, S.C., Tanik, U.J., Carbone, J.N., Eroglu, A., Eds.; Springer: London, UK, 2014; pp. 15-32. [CrossRef]

23. Fedotov, A.; Fedotov, A.; Tolstik, A.; Zabasta, A.; Žiravecka, A.; Kunicina, N.; Ribickis, L. Evaluation of Market Needs in Belarus for Improvement of Master-Level Education in the Field of Physical Sciences. In Proceedings of the 57th International Scientific Conference on Power and Electrical Engineering of Riga Technical University, Riga, Latvia, 13-14 October 2016; pp. 1-6. [CrossRef]

24. Peuteman, J.; Janssens, A.; De Craemer, R.; Boydens, J.; Zabašta, A.; Fedotov, A. Integration of the European bachelor master degree concept at Belarusian universities for physics and engineering students. In Proceedings of the XXV International Scientific Conference Electronics_ET2016, Sofia Technical University, Sozopol, Bulgaria, 12-14 September 2016; pp. 47-50. [CrossRef]

25. Zabasta, A.; Kunicina, N.; Nikiforova, O.; Romanovs, A. Multi-Paradigm Modelling for Cyber-Physical Systems. How to Exploit an Experience Gained in CPS Related Projects for Master Students Training Program in ERASMUS+ Project. In Proceedings of the 5th Workshop of the MPM4CPS COST Action, Malaga, Spain, 24-25 November 2016; pp. 206-221.

26. Zabasta, A.; Carreira, P.; Nikiforova, O.; Amaral, V.; Kunicina, N.; Goulão, M.; Sukovskis, U.; Ribickis, L. Developing a Mutually-Recognized Cross-Domain Study Program in Cyber-Physical Systems. In Proceedings of the 2017 IEEE Global Engineering Education Conference EDUCON, Athens, Greece, 25-28 April 2017; pp. 791-799. [CrossRef]

27. Zabasta, A.; Zhiravetska, A. Report on Surveys of Industry Representatives and Other Stakeholders, Deliverable 2 of the Erasmus+ Project Development of Practically-Oriented Student-Centered Education in the Field of Modelling of Cyber-Physical Systems. Available online: https://cybphys.rtu.lv/ (accessed on 29 July 2020).

28. Gnatov, A.; Argun, S.; Ulyanets, O. Joint innovative double degree master program energy-saving technologies in transport. In Proceedings of the 2017 IEEE First Ukraine Conference on Electrical and Computer Engineering UKRCON, Kiev, Ukraine, 29 May-2 June 2017; pp. 1203-1207. [CrossRef]

29. Danielis, R.; Giansoldati, M.; Rotaris, L. A probabilistic total cost of ownership model to evaluate the current and future prospects of electric cars uptake in Italy. Energy Policy 2018, 119, 268-281. [CrossRef]

30. Hnatov, A.; Arhun, S.; Tarasov, K.; Hnatova, A.; Migal, V.; Patlins, A. Researching the Model of Electric Propulsion system for bus with the Matlab Simulink. In Proceedings of the 2019 IEEE 60th International Scientific Conference on Power and Electrical Engineering of Riga Technical University (RTUCON), Riga, Latvia, 7-9 October 2019; pp. 1-6. [CrossRef]

31. Serrano, J.R. Imagining the future of the internal combustion engine for ground transport in the current context. Appl. Sci. 2017, 7, 1001. [CrossRef]

32. Arhun, S.; Hnatov, A.; Dziubenko, O.; Ponikarovska, S. A device for converting kinetic energy of press into electric power as a means of energy saving. J. Korean Soc. Precis. Eng. 2019, 36, 105-110. [CrossRef]

33. Patlins, A.; Hnatov, A.; Arhun, S. Safety of Pedestrian Crossings and Additional Lighting Using Green Energy, in Transport Means 2018. In Proceedings of the 22nd International Scientific Conference, Trakai, Kaunas, Lithuania, 5 October 2018; pp. 527-531, ISBN 1822-296X/e-ISSN 2351-7034.

34. Hnatov, A.; Arhun, S.; Ponikarovska, S.; Ulyanets, O. Ultracapacitors electrobus for urban transport. In Proceedings of the IEEE 38th International Conference on Electronics and Nanotechnology ELNANO, Kyiv, Ukraine, 24-26 April 2018; pp. 539-543. [CrossRef]

35. Multi-Paradigm Modelling for Cyber-Physical Systems (MPM4CPS) COST Action IC1404. Available online: http://www.cost.eu/COST_Actions/ict/IC1404?parties (accessed on 5 August 2020).

Publisher's Note: MDPI stays neutral with regard to jurisdictional claims in published maps and institutional affiliations. 
(C) 2020 by the authors. Licensee MDPI, Basel, Switzerland. This article is an open access article distributed under the terms and conditions of the Creative Commons Attribution (CC BY) license (http://creativecommons.org/licenses/by/4.0/). 